\title{
How drought severity constrains gross primary production(GPP) and its partitioning among carbon pools in a Quercus ilex coppice?
}

\author{
S. Rambal ${ }^{1,5}$, M. Lempereur ${ }^{1,6}$, J. M. Limousin ${ }^{2}$, N. K. Martin-StPaul ${ }^{1,3,7}$, J. M. Ourcival ${ }^{1}$, and \\ J. Rodríguez-Calcerrada ${ }^{4}$ \\ ${ }^{1}$ Centre d'Ecologie Fonctionnelle et Evolutive CEFE, UMR5175, CNRS, Université de Montpellier, \\ Université Paul-Valéry Montpellier, EPHE 1919 Route de Mende, 34293 Montpellier, Cedex 5, France \\ ${ }^{2}$ Department of Biology, University of New Mexico, MSC03 2020, Albuquerque, New Mexico 87131-0001, USA \\ ${ }^{3}$ Laboratoire Ecologie Systématique et Evolution CNRS, Orsay, 91405, France \\ ${ }^{4}$ Grupo de Investigación en Genética y Fisiología Forestal, E.T.S.I. Montes, Universidad Politécnica de Madrid, \\ Ciudad Universitaria S/N., 28040 Madrid, Spain \\ ${ }^{5}$ Universidade Federal de Lavras, Departamento de Biologia, CP 3037, CEP 37200-000, Lavras, MG, Brazil \\ ${ }^{6}$ Agence de l'Environnement et de la Maîtrise de l'Energie 20, avenue du Grésillé, BP 90406, \\ 49004 Angers, Cedex 01, France \\ ${ }^{7}$ INRA, URFM, Ecologie des Forêts Méditerranéennes, UR629, Domaine Saint Paul, Site Agroparc, \\ 84914 Avignon, Cedex 9, France
}

Correspondence to: S. Rambal (serge.rambal@cefe.cnrs.fr)

Received: 15 May 2014 - Published in Biogeosciences Discuss.: 11 June 2014

Revised: 22 October 2014 - Accepted: 30 October 2014 - Published: 9 December 2014

\begin{abstract}
The partitioning of photosynthates toward biomass compartments plays a crucial role in the carbon $(\mathrm{C})$ sink function of forests. Few studies have examined how carbon is allocated toward plant compartments in droughtprone forests. We analyzed the fate of gross primary production (GPP) in relation to yearly water deficit in an old evergreen Mediterranean Quercus ilex coppice severely affected by water limitations. Carbon fluxes between the ecosystem and the atmosphere were measured with an eddy covariance flux tower running continuously since 2001. Discrete measurements of litterfall, stem growth and $f_{\text {APAR }}$ allowed us to derive annual productions of leaves, wood, flowers and acorns, and an isometric relationship between stem and belowground biomass has been used to estimate perennial belowground growth. By combining eddy covariance fluxes with annual net primary productions (NPP), we managed to close a $\mathrm{C}$ budget and derive values of autotrophic, heterotrophic respirations and carbon-use efficiency (CUE; the ratio between NPP and GPP). Average values of yearly net ecosystem production (NEP), GPP and $R_{\text {eco }}$ were 282 , 1259 and $977 \mathrm{~g} \mathrm{C} \mathrm{m}^{-2}$. The corresponding aboveground net primary production (ANPP) components were 142.5, 26.4
\end{abstract}

and $69.6 \mathrm{~g} \mathrm{C} \mathrm{m}^{-2}$ for leaves, reproductive effort (flowers and fruits) and stems, respectively. NEP, GPP and $R_{\text {eco }}$ were affected by annual water deficit. Partitioning to the different plant compartments was also impacted by drought, with a hierarchy of responses going from the most affected - the stem growth - to the least affected - the leaf production. The average CUE was 0.40 , which is well in the range for Mediterranean-type forest ecosystems. CUE tended to decrease less drastically in response to drought than GPP and NPP did, probably due to drought acclimation of autotrophic respiration. Overall, our results provide a baseline for modeling the inter-annual variations of carbon fluxes and allocation in this widespread Mediterranean ecosystem, and they highlight the value of maintaining continuous experimental measurements over the long term.

\section{Introduction}

Forest ecosystems exert a strong influence on the global carbon (C) cycle (Bonan, 2008) as forests may contribute up to $60 \%$ of the total land carbon uptake (Beer et al., 
2010). Estimations and simulations of carbon uptake by forest ecosystems have been greatly improved in recent decades, but, unfortunately, how this assimilated $\mathrm{C}$ is transferred from the atmosphere to the terrestrial biomass remains a challenging issue. Luo et al. (2011) highlighted a lack of mechanistic understanding on this question and suggested developing "generalizable models of $\mathrm{C}$ allocation to biomass growth of plant parts, respiration, nonstructural $\mathrm{C}$ reserve, reproduction and defense". A recent synthesis has demonstrated that the partitioning of gross primary production (GPP), among aboveground and belowground production and respiration, can vary greatly across biomes, according to climate and fertility (Litton and Giardina, 2008). However, a more detailed understanding of how environmental factors affect the distribution of $\mathrm{C}$ among the different tree parts at the ecosystem scale remains a crucial step to improving the accuracy of local and global vegetation models (Fatichi et al., 2013; Leuzinger and Quinn Thomas, 2011).

Understanding $\mathrm{C}$ allocation patterns appears particularly important in drought-prone areas, such as those with a Mediterranean-type climate, which are particularly vulnerable to ongoing climate change (Giorgi, 2006). According to global and regional climate models, Mediterraneantype ecosystems (MTEs) will suffer longer and more intense droughts as a result of (1) increasing temperature and decreasing rainfall (Hoerling et al., 2011), (2) a change in largescale circulation conditions (Kjellström et al., 2013), and (3) the persistence of heat wave anomalies (Jaeger and Seneviratne, 2011). In MTEs, drought is already the prevailing constraint on the net ecosystem productivity (NEP) (Allard et al., 2008; Grünzweig et al., 2003). This sink strength is likely modified by the differential sensitivity to water limitation of leaf photosynthesis and whole-tree respiration, and of the $\mathrm{C}$ allocation to short- and long-lived pools. The representation of $\mathrm{C}$ use in models currently lacks consensus and is achieved by a plethora of concurrent approaches (Franklin et al., 2012). This modeling deficiency seems to be due to the difficulty in interpreting this information in generic schemes that are valid under a wide range of conditions, particularly water limitation.

So far, studies addressing the question of $\mathrm{C}$ use in MTEs have relied on the coupling of field data of standing biomass and growth compartments with simulation models. Pioneering works started in the 1970s onwards (Eckardt et al., 1975). Oechel and Lawrence (1981) applied the process-based model MEDECS to eight woody Mediterranean species growing in California chaparral and Chilean matorral. The model scaled up leaf level respiration and assimilation, together with stem respiration to yield yearly $\mathrm{C}$ budgets using a radiation transfer scheme. The hierarchy of $\mathrm{C}$ allocation to leaves, stems and roots followed species-specific rules and a phenological calendar. From this modeling exercise, the authors deduced changes in $\mathrm{C}$ use that deeply modified the respiratory costs in response to changes in air temperature. Yet, the effect of drought on $\mathrm{C}$ use remains more difficult to understand and simulate.

Forests and woodlands dominated by the evergreen oak Quercus ilex L. (hereafter $Q$. ilex) occupy large areas in the surrounding area of the Mediterranean Sea (Quézel and Médail, 2003) and are emblematic of the MTEs. Due to its resprouting nature, $Q$. ilex can remain in the same place for hundreds of years, and populations display minimal changes in stool number per area. Very high survival rates and fast recovery of its foliage after complete dieback (Lloret et al., 2004) reflect its high ability to survive in damping climate extremes (Misson et al., 2011). In contrast, co-occurring obligate seeders are subjected to all the vicissitudes of regeneration, and are particularly affected by drought mortality at the seedling stages and by wildfires (Ackerly, 2004; Zavala, 1999). The growing interest in resprouting ability as a major plant functional trait is reflected in a number of recent contributions aimed at understanding the biogeography at developing functional models of resprouting species (Clarke et al., 2010; Vesk and Westoby, 2004; Vilagrosa et al., 2014). Resprouters have the particularity to store considerable amounts of $\mathrm{C}$ belowground at the cost of high maintenance respiration (Iwasa and Kubo, 1997). Characterizing the ecosystem C use for such species is important for managing and predicting the response of Mediterranean forests to the ongoing climate changes.

The functioning of Quercus ilex stands in the south of France was simulated by Hoff et al. (2002) and Hoff and Rambal (2003) using the Forest-BGC model. C use rules in this simple model are implemented so as to follow an optimal trajectory: trees use $\mathrm{C}$ first into leaves and fine roots for maximizing productivity, while minimizing water limitation; finally, stems appear as an end product built with the remaining C. Other modeling exercises with $Q$. ilex ecosystems also retained water-related constraints for their $\mathrm{C}$ use rules. Gracia et al. (1999) developed a dynamic growth model, where the partitioning of growth between leaves and perennial wood compartments is performed so as to fulfill the assumptions of the pipe model theory (Shinozaki et al., 1964; see also Mäkelä, 1986 for substantial accounts; Valentine, 1985); i.e., so as to maintain the sap area/foliage area ratio constant. Gracia et al. (1999) also constrain growth to fine roots to follow the functional balance hypothesis (Brouwer, 1962). Both of the abovementioned modeling exercises yielded credible results when validated against yearly variations of radial growth. Fortunately, the increasing availability of longterm field measurements of productivity and eddy covariance fluxes can now help to refine these previous modeling hypotheses.

In this study, our main objectives were: (1) to evaluate the fraction of GPP partitioned to aboveground and belowground parts in a Quercus ilex forest by comparing different ecosystems across a range of climate, management and drought resistance of dominant species, and (2) to assess how year-toyear variation in drought severity impacts the partitioning of 
GPP between production and respiration, and among aboveground and belowground $\mathrm{C}$ pools. For these purposes, we used long-term data of eddy covariance fluxes and primary productivity of aboveground components (leaves, flowers, fruits and stems), plus punctual data of root biomass taken from literature and our own excavation of four $Q$. ilex trees.

\section{Material and methods}

\subsection{Site description}

The study site is located $35 \mathrm{~km}$ northwest of Montpellier (south of France), on a flat plateau in the Puéchabon State forest $\left(3^{\circ} 35^{\prime} 45^{\prime \prime} \mathrm{E}, 43^{\circ} 44^{\prime} 29^{\prime \prime} \mathrm{N} ; 270 \mathrm{~m}\right.$ a.s.1.). This forest has been managed as a coppice for centuries, and the last clear cut was performed in 1942. Vegetation is largely dominated by a dense overstorey of the evergreen oak Quercus ilex. The top canopy height is about $5.5 \mathrm{~m}$. In 2010, stem density was 4900 stems $\times \mathrm{ha}^{-1}$. Stems with diameter at breast height $(\mathrm{DBH})<4 \mathrm{~cm}$ represented $6 \%$ of total stems, whereas those with $D B H>10 \mathrm{~cm}$ represented $20.6 \%$. Understorey species Buxus sempervirens, Phyllirea latifolia, Pistacia terebinthus and Juniperus oxycedrus compose a sparse shrubby layer with a percentage cover lower than $25 \%$ and a height less than $2 \mathrm{~m}$.

The area has a Mediterranean-type climate. Rainfall mainly occurs during autumn and winter, with about $80 \%$ taking place between September and April. The mean annual precipitation is $916 \mathrm{~mm}$, with a range of 556-1549 mm recorded over the 1984-2011 period. Mean annual temperature over the same period was $13.0^{\circ} \mathrm{C}$, with a minimum in January $\left(5.5^{\circ} \mathrm{C}\right)$ and a maximum in July $\left(22.9^{\circ} \mathrm{C}\right)$. The rocky soil is formed on Jurassic limestone; on average, the volumetric fractional content of stones and rocks is about 0.75 for the top $0-50 \mathrm{~cm}$ and 0.90 below. The stone-free fine fraction of the soil is a homogeneous silty clay loam (USDA texture triangle) within the top $0-50 \mathrm{~cm}$ layer $(38.8 \%$ clay, $35.2 \%$ silt and $26 \%$ sand). The fine fraction fills up the space between stones and rocks, and provides a source of water throughout the long dry summers for the deep-rooted $Q$. ilex (Rambal, 2011). The highly permeable soil prevents any surface runoff to occur even for high intensity rain events.

\subsection{Water limitation: soil water balance model and drought index}

Soil water storage integrated over the rooting depth, that is ca. $4.5 \mathrm{~m}$ (Rambal, 2011), has been measured during the vegetative periods of 1984-1986 and since July 1998 onwards, at approximately monthly intervals, using a neutron moisture gauge (see Hoff et al., 2002). Discrete measurements were interpolated at a daily time step with a soil water balance model proposed in Rambal (1993) and further used in Grote et al. (2009). The drainage curve relating deep drainage to soil water storage depends on the stone content over the whole-soil profile (Rambal, 1990). The model was driven by daily values of incoming solar radiation, minimal and maximal temperature and rain amount. Soil water storage and soil water potential were related by a Campbell-type retention curve (Campbell, 1985) whose parameters are strongly dependent on soil texture (see details in Rambal et al., 2003). Comparison of measured against simulated values of soil water storage (in $\mathrm{mm}$ ) and predawn leaf water potential (in $\mathrm{MPa}$ ) displayed very good agreement. Leaf water potential values came from discrete measurements performed on the study site (see Limousin et al., 2012 for a substantial account). For soil water storage, reduced major axis (RMA) regressions yielded $\mathrm{SWS}_{\mathrm{sim}}=\alpha_{\mathrm{rma}} \mathrm{SWC}_{\mathrm{obs}}+\beta_{\mathrm{rma}}$ with $\alpha_{\mathrm{rma}} \pm$ standard error $(\mathrm{SE})=0.94 \pm 0.03, \beta_{\mathrm{rma}} \pm \mathrm{SE}=6.0 \pm 4.4, R^{2}=0.93$, $F=1137, p<0^{\circ} .0001$ and $n=91$; for the predawn potential, $\psi_{\text {pdsim }}=\alpha_{\text {rma }} \psi_{\text {pdobs }}+\beta_{\text {rma }}$ with $\alpha_{\text {rma }} \pm \mathrm{SE}=0.93 \pm 0.05$, $\beta_{\mathrm{RMA}} \pm \mathrm{SE}=-0.09 \pm 0.09, \quad R^{2}=0.840, \quad F=273.3$, $p<0.0001$ and $n=54$. The continuous daily course of relative water content, RWC, was derived from $\mathrm{SWS}_{\text {sim }}$ divided by the soil water storage at a field capacity that we chose to fix at $205 \mathrm{~mm}$. This value corresponds to that observed after 2 days of free drainage in a cool, wet period after a substantial rain event. For characterizing the whole-year water limitation, we calculated the water stress integral (WSI) as the yearly sum of $\psi_{\text {pdsim }}$. For days with $\mathrm{RWC} \geq 1$, $\psi_{\text {pdsim }}$ is fixed to $-0.03 \mathrm{MPa}$. The WSI is expressed in $\mathrm{MPa}$ day.

\subsection{Drought frequency analysis}

The return periods for drought events were calculated using a monthly 239-year precipitation historical data set (17622011) for downtown Montpellier. This data set was scaled to our experimental site using overlapping precipitation data from 1984 to 2011. As shown by Rambal and Debussche (1995) and López-Moreno et al. (2009), the coefficient of variation for precipitation is regionally conserved and was used to fit theoretical lognormal distribution functions for extreme precipitation events at our site. Return periods were calculated as $1 / p$, where $p$ is the probability of occurrence (Rambal and Debussche, 1995).

\subsection{Carbon fluxes and ancillary data}

Daily climate data, further used as model inputs for a water budget model, came from a weather station located $200 \mathrm{~m}$ away from the flux tower.

Eddy covariance fluxes of $\mathrm{CO}_{2}$, sensible heat, latent heat and momentum were measured continuously since 2001 at the top of a $12 \mathrm{~m}$ high tower that was approximately $6 \mathrm{~m}$ above the canopy. Our eddy covariance facility included a three-dimensional sonic anemometer (Solent R3, Gill Instruments, Lymington, England) and a closed path infrared gas analyzer (IRGA; model LI 6262) (Li-Cor Inc., 
Lincoln, Nebraska, USA), both sampling at a rate of $21 \mathrm{~Hz}$. Flux data were processed with protocols defined within the Carbo-Europe network (www.carboeurope.org, Aubinet et al., 2000). Processing schemes of FLUXNET have been used for filling data gaps and partitioning NEP into GPP and ecosystem respiration $R_{\text {eco }}$ (Papale, 2006; Reichstein et al., 2005). The half-hourly fluxes were summed at yearly time steps for further analysis. Photosynthetically active radiation PAR $_{\text {top }}$ was recorded at the top of the flux tower. Photosynthetically active radiation (PAR) was recorded at the top of

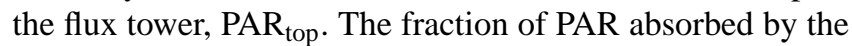
canopy $\left(f_{\text {APAR }}\right)$ was derived from 14 PAR sensors randomly set up in understorey locations and measuring $\mathrm{PAR}_{\text {below: }}$

$$
f_{\text {APAR }}=1-\text { PAR }_{\text {below }} / \mathrm{PAR}_{\text {top }} \text {. }
$$

\subsection{Leaf production and other growth components}

$\mathrm{ANPP}_{\text {stem }}$ was estimated from yearly measurements of stem $\mathrm{DBH}$ and the allometric relationship between stem biomass and stem DBH. ANPP leaf $_{\text {and }} \mathrm{ANPP}_{\text {reprod }}$ were derived from monthly litter falls measured on 26 litter traps of $0.141 \mathrm{~m}^{2}$ area. $\mathrm{ANPP}_{\text {reprod }}$ comprised flowers and acorns. $\mathrm{ANPP}_{\text {leaf }}$ was derived by estimating yearly changes of leaf mass at peak leaf area index plus the amount of leaves lost as litter. Leaf production in year $t$ occurred from May to June, and $M_{\text {leaflitter was calculated as the sum of monthly values of leaf }}$ litter fallen from August $t-1$ to July $t$. M leaflitter was corrected for mass loss at abscission, using the results of Cherbuy et al. (2001):

$$
\begin{aligned}
& \mathrm{ANPP}_{\text {leaf }}=M_{\text {leaf }}(t)-M_{\text {leaf }}(t-1)+M_{\text {leaflitter }} \\
& =\Delta M_{\text {leaf }}+M_{\text {leaflitter }}
\end{aligned}
$$

Peak LAI = PAI-SAI was estimated from continuous measurements of half-hourly $f_{\text {APAR }}$ between 11.00 a.m. and 1.00 p.m. from day of year (DOY) 205 to 225. We first derived the plant area index (PAI) by using Beer's law with an extinction parameter equal to $k / \sin \beta$. The parameter $k$ was set to 0.72 as in Rambal et al. (2003), and $\beta$ is the solar elevation angle. The stem area index (SAI) was estimated by image processing of hemispheric photography. It was assumed constant for the whole period and equal to 0.5 (Poncelet's unpublished data). LAI was converted to leaf mass with a canopy-averaged leaf mass per area of $215 \mathrm{~g} \mathrm{~m}^{-2}$ (see Rambal et al., 1996). The below-canopy PAR sensor network was set up in 2001, so the leaf production for 2001 was not available. Even though $Q$. ilex is a strong emitter of terpenoids (Staudt et al., 2002), biogenic volatile compound emissions are relatively minor $\mathrm{C}$ sources and they were neglected here. So, the aboveground net production was computed as

$$
\mathrm{ANPP}=\mathrm{ANPP}_{\text {leaf }}+\mathrm{ANPP}_{\text {stem }}+\mathrm{ANPP}_{\text {reprod }} .
$$

In 2005, we observed a massive outburst of Lymantria dispar. Grazing from caterpillars drastically impacted the leaves, so we decided to exclude data from 2005 in our calculations. Data for the belowground perennial components were obtained by excavating four stumps at our site and from literature values published by Canadell and Roda (1991) and Djema (1995) for $Q$. ilex coppices growing in northeast Spain under similar climate conditions. We compiled 19 biomass values for root crown, roots greater than $5 \mathrm{~cm}$, and roots ranging from 1 to $5 \mathrm{~cm}$ diameter. The whole perennial belowground compartment is the sum of root crown and large roots. We obtained an isometric relationship between stem and belowground biomass, with a slope equal to $1.068 \pm 0.1235$ $\left(s_{x, y}=62.2, n=19, p<0^{\circ} .001\right)$ (Appendix Fig. A1). All these data came from excavations in very stony soils and only concerned the top 0-1 m layer. A significant part of the root system was not extracted, because we observed that tap roots are able to uptake soil water at depths ranging between 4 and $5 \mathrm{~m}$ (Rambal, 2011). We thus applied a conservative correction factor of $10 \%$ to account for the missing root part. Our belowground / aboveground ratio could be considered constant whatever the stool size, so we propose an isometric partition of $\mathrm{C}$ between these two perennial compartments. We postulate that the error we made in estimating $\mathrm{BNPP}_{\text {coarse }}$ is equivalent to the one we made in evaluating the change in stem biomass:

$\alpha \mathrm{ANPP}_{\text {stem }}=\mathrm{BNPP}_{\text {coarse }}$,

with BNPP representing belowground net primary production. Fine root production was taken from literature values. López et al. (2001a) extensively monitored fine root productivity in a $Q$. ilex coppice. They found annual fine root production over the $0-60 \mathrm{~cm}$ soil layer to be quasi identical to leaf production (average fine root/ leaf production ratio over 2 years was 1.04). We correct this value for the whole profile using a ratio of 1.25 , based on the distribution of fine roots over the soil profile proposed by Jackson et al. (1997) for sclerophyllous shrubs and trees, and the increase in fine root turnover rate with depth (López et al., 2001b):

$\mathrm{BNPP}=\mathrm{BNPP}_{\text {coarse }}+\mathrm{BNPP}_{\text {fine }}$.

Biomasses were converted to $\mathrm{C}$ using tissue-specific $\mathrm{C}$ contents whenever available; otherwise, 0.48 was used as a default.

\subsection{Carbon budget estimate}

The different components of the carbon budget were related to each other according to three identities considered here as yearly sums (Fig. 1):

$$
\begin{aligned}
& \mathrm{NPP}=\mathrm{ANPP}+\mathrm{BNPP}=\mathrm{GPP}-R_{\mathrm{a}}, \\
& \mathrm{NEP}=\mathrm{NPP}-R_{\mathrm{h}}=\mathrm{GPP}-R_{\mathrm{eco}}, \\
& R_{\mathrm{eco}}=R_{\mathrm{a}}+R_{\mathrm{h}} .
\end{aligned}
$$

$R_{\mathrm{a}}$ is the autotrophic respiration, including both growth and maintenance components, with $R_{\mathrm{aa}}$ and $R_{\mathrm{ab}}$ standing for 




Figure 1. Method used in closing the whole-ecosystem carbon balance. Arrows are the information lines. The grey boxes surrounded by a continuous line are the ecosystem scale flux measurements yielding NEP, GPP and $R_{\text {eco }}$ values. The green boxes are the continuous biometric measurements of the growth components. The boxes surrounded by a dashed line mean discrete measurements. The brown boxes are discrete measurements of fluxes (from leaf, stem and soil) upscaled in time and space.

the aboveground and belowground parts, respectively. $R_{\mathrm{h}}$ is the heterotrophic respiration. Uncertainty estimation of fluxes were around $20 \mathrm{~g} \mathrm{C} \mathrm{m}^{-2} \mathrm{yr}^{-1}, 30 \mathrm{~g} \mathrm{C} \mathrm{m}^{-2} \mathrm{yr}^{-1}$ and $40 \mathrm{~g} \mathrm{C} \mathrm{m}^{-2} \mathrm{yr}^{-1}$ for NEE, GPP and $R_{\text {eco }}$, respectively (Misson et al., 2010; see also Stauch et al., 2008).

$\mathrm{GPP}=\mathrm{ANPP}+R_{\mathrm{aa}}+\mathrm{TBCF}$

Total belowground carbon flux (TBCF) was defined as carbon allocated belowground by plants to coarse and fine roots production, root respiration and root exudates and mycorrhizae. TBCF is either respired by microbes or roots (measured as soil-surface $\mathrm{CO}_{2}$ efflux) or stored in soil as organic matter in the litter layer or in living and dead roots. Growth respiration was calculated using the yield of growth processes $Y$ (Thornley, 1970). This yield is the amount of biomass increment per unit of $\mathrm{C}$ substrate used in growth processes. It was expressed in $\mathrm{g} \mathrm{C}$ of new biomass ( $\mathrm{g} \mathrm{C}$ of substrate used in the growth processes) $)^{-1}$. For $Q$. ilex in Puéchabon, the $Y$ parameter has been estimated to $0.8 \mathrm{~g} \mathrm{C}$ appearing in new biomass per $\mathrm{g}$ of $\mathrm{C}$ substrate utilized (Rambal et al., 2004). In Eqs. (6), (7) and (9), we neglect nonstructural $\mathrm{C}$ storage above or belowground. In the carbon budget, we wrote an equation in which $\mathrm{C}$ balance is 0 , independently of the water limitation, and consequently the storage of nonstructural C pool remains constant (see Ryan, 2011; Sala et al., 2010; Wiley and Helliker, 2012 for the role of nonstructural carbohydrates in coping with drought).

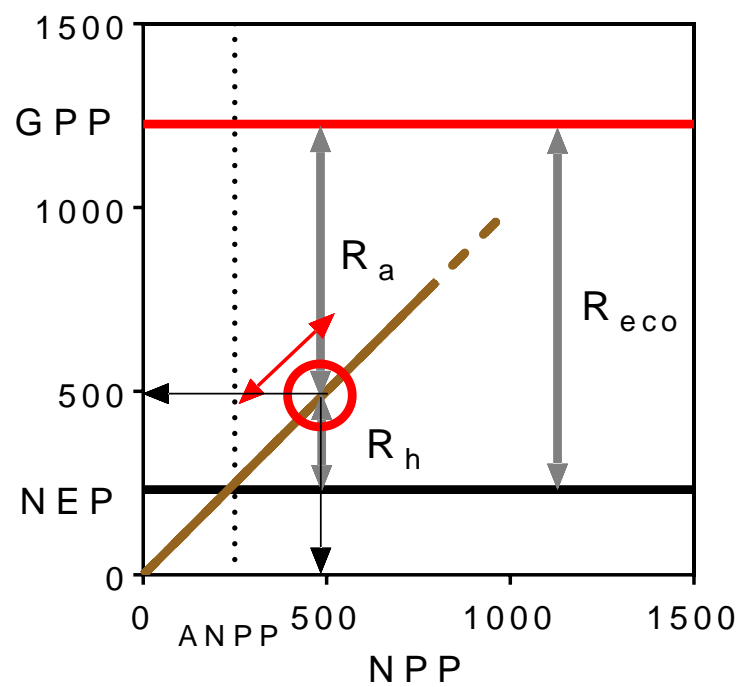

Figure 2. Scheme showing how the biometric estimate of NPP determines the partition of $R_{\mathrm{eco}}$ in its components $R_{\mathrm{a}}$ and $R_{\mathrm{h}}$. In this figure, we plot GPP, NEP and NPP at their average values. The red arrow shows how errors in estimating NPP propagate in $R_{\mathrm{a}}$ and $R_{\mathrm{h}}$ All variables are expressed in $\mathrm{g} \mathrm{C} \mathrm{m}^{-2} \mathrm{yr}^{-1}$.

\section{Results}

\subsection{Environmental conditions and exceptional years}

Over the study period (2001-2011), annual rain amounts ranged from $638.2 \mathrm{~mm}$ in 2007 to $1310 \mathrm{~mm}$ in 2003. The average value over this period $(976.8 \mathrm{~mm})$ was slightly greater than the longer term mean $(1984-2011 ; 916 \mathrm{~mm})$. WSI ranged from $-112.6 \mathrm{MPa}$ day in the wettest year (2004) to $-358.6 \mathrm{MPa}$ day in the driest year (2006). There was no relationship between the annual rainfall amount and the annual WSI that the vegetation underwent. Lower WSI occurred in years when the dry period began early in the spring season. In the driest year (2006), the rain deficit began in February, and from February to June the rainfall amount reached only $109.8 \mathrm{~mm}$. We calculated a probability of 0.015 for the 2006 drought, corresponding to a return period of $67 \mathrm{yr}$. Other years with dry spring seasons in the historical series were 1779, 1780, 1817, 1929, 1945 and 1995, but all these years displayed less severe droughts than 2006. So, over the 20012011 period, we observed a very large range of water limitation from well-watered conditions to severe drought. There was no significant covariation between mean annual temperature and WSI.

\subsection{C fluxes and production}

The mean gross $\mathrm{C}$ input (GPP) was $1259 \mathrm{~g} \mathrm{C} \mathrm{m}^{-2} \mathrm{yr}^{-1}$ and its coefficient of variation (CV), or between-year variation, was $13.3 \%$. For NEP, the mean value was 


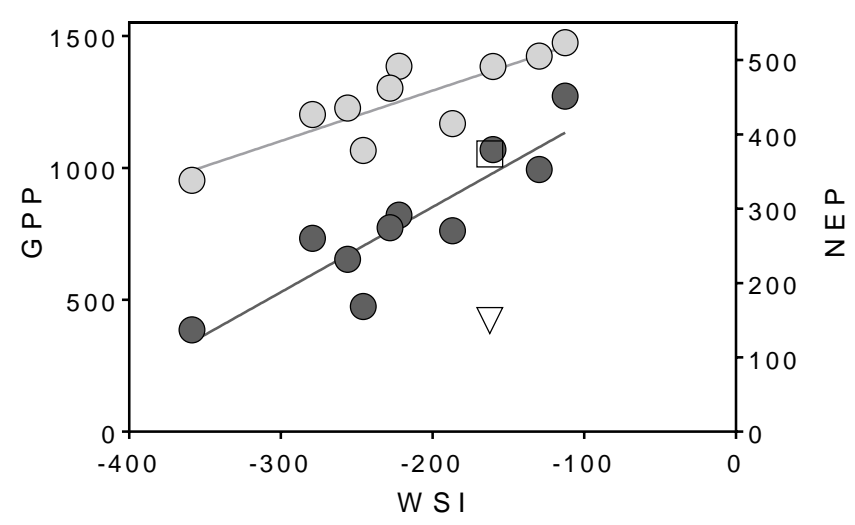

Figure 3. Ordinary least-square regression lines between the WSI and gross primary production GPP (light grey circle) and NEP (dark grey circle). WSI is expressed in MPa day, and both GPP and NEP are expressed in $\mathrm{g} \mathrm{C} \mathrm{m}^{-2} \mathrm{yr}^{-1}$. Data from 2005 that were not used in the analysis were also plotted (empty square for GPP and empty triangle for NEP).

$281.7 \mathrm{~g} \mathrm{C} \mathrm{m}^{-2} \mathrm{yr}^{-1}$ with a larger $\mathrm{CV}$ of $33.5 \%$, and for $R_{\mathrm{eco}}$, it was $977.2 \mathrm{~g} \mathrm{C} \mathrm{m}^{-2} \mathrm{yr}^{-1}$, with a $\mathrm{CV}=8.9 \%$ (Fig. 2).

The average LAI was $2.25 \pm 0.2$, which corresponds to a supported leaf mass of $231.7 \mathrm{~g} \mathrm{C} \mathrm{m}^{-2}(n=10)$ with a coefficient of variation of $\mathrm{CV}=9 \%$ (Fig. A2.). Our calculation of the leaf production yields an average value of $142.5 \mathrm{~g} \mathrm{C} \mathrm{m}^{-2} \mathrm{yr}^{-1}(n=9)$ with a large CV of $28.5 \%$. The leaf production ranged from $202.8 \pm 77.1 \mathrm{~g} \mathrm{C} \mathrm{m}^{-2} \mathrm{yr}^{-1}$ in 2006, the year after the Lymantria dispar outburst and heavy grazing, to $69.6 \pm 58.2 \mathrm{~g} \mathrm{C} \mathrm{m}^{-2} \mathrm{yr}^{-1}$ the following year in 2007. The reproductive effort, $\mathrm{ANPP}_{\text {reprod, }}$, evaluated in pooling flowers and acorns, displayed the greater between-year variation, with a $42.5 \% \mathrm{CV}$, and a mean value of $26.4 \mathrm{~g} \mathrm{C} \mathrm{m}^{-2}$. The components of $\mathrm{ANPP}_{\text {reprod }}$ were, on average, $11.0 \mathrm{~g} \mathrm{C} \mathrm{m}^{-2} \mathrm{yr}^{-1}$ for flowers $(\mathrm{CV}=48.5 \%)$ and $15.4 \mathrm{~g} \mathrm{C} \mathrm{m}^{-2} \mathrm{yr}^{-1}$ for acorns, which displayed the largest variation $(\mathrm{CV}=87.8 \%)$. Summing leaves plus flowers and acorns, we obtained an average $169.6 \mathrm{~g} \mathrm{C} \mathrm{m}^{-2} \mathrm{yr}^{-1}$, which accounted only for $16.9 \%$ of the yearly GPP.

\subsection{Relationships between production components and water limitation}

Significant linear declines of GPP, NEP and $R_{\text {eco }}$ with increasing drought severity were observed across years (Table 1; Fig. 3). Respectively, 72 and $80 \%$ of the variance in GPP and NEP was explained by the WSI. The slopes of the GPP and NEP vs. WSI lines were $1.91 \pm 0.43$ and $1.15 \pm 0.20$, respectively, which means that we project a decline of GPP of $191 \mathrm{~g} \mathrm{C} \mathrm{m}^{-2} \mathrm{yr}^{-1}$ and of NEP of $115 \mathrm{~g} \mathrm{C} \mathrm{m}^{-2} \mathrm{yr}^{-1}$ for an increase in drought severity of 100 MPa day, expressed in terms of WSI. The sensitivity to drought of $R_{\text {eco }}$ was lower than that for the two other components of the whole-ecosystem $\mathrm{C}$ budget, with a lower slope

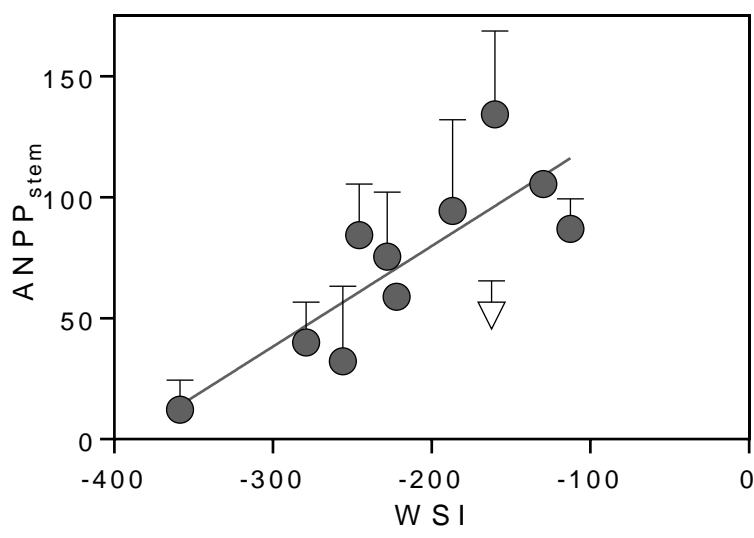

Figure 4. Ordinary least-square regression line between the WSI and the net production of stems (error bars are standard deviation). WSI is expressed in MPa day and $\mathrm{ANPP}_{\text {stem }}$ in $\mathrm{g} \mathrm{C} \mathrm{m}^{-2} \mathrm{yr}^{-1}$. Data from 2005 that were not used in the analysis were also plotted (empty triangle).

of $0.77 \pm 0.32$ associated with a lower explained variance of $42 \%$.

Among the aboveground tree compartments, the most affected by drought was the stem (Fig. 4), with $\mathrm{dANPP}_{\text {stem }} / \mathrm{dWSI}=0.42 \pm 0.10$ (Table 1; Fig. 4). According to the linear equation fitted between $\mathrm{ANPP}_{\text {stem }}$ and WSI, the predicted allocation of $\mathrm{C}$ to the stem ranged from $120.9 \mathrm{~g} \mathrm{C} \mathrm{m}^{-2}$ for a hypothetic wet year that underwent a WSI of $-100 \mathrm{MPa}$ day (WSI in 2004 equaled $-112.6 \mathrm{MPa}$ day), to 0 in a severely dry year with a WSI of $-390 \mathrm{MPa}$ day. Reproduction was also affected by water stress, with dANPP reprod $/ \mathrm{dWSI}=0.10 \pm 0.04$ (Fig. 5). In contrast, no significant relationship was found between WSI and $\mathrm{ANPP}_{\text {leaf }}(p=0.54$; Table 1, Fig. 6b). ANPP leaf was, however, significantly related to the WSI of the previous year, with a slope of $0.41 \pm 0.15$ and an explained variance of $52 \%$ (Fig. 6a).

\subsection{Relationship between carbon-use efficiency (CUE) and water limitation}

By combining the latter results with Eqs. (6) to (9), a model of $\mathrm{C}$ use changes not in drought severity can be proposed. Figure 7a depicts the changes of GPP and NPP, and of the above and belowground compartments with WSI. Carbon-use efficiency (CUE $=$ NPP / GPP) is also presented. For WSI declining from $-100 \mathrm{MPa}$ day in a wet year to $-400 \mathrm{MPa}$ day in a particularly dry year, NPP and CUE decline from 621.4 to $339.4 \mathrm{~g} \mathrm{C} \mathrm{m}^{-2} \mathrm{yr}^{-1}$ and from 0.419 to 0.373 , respectively.

Figure $7 \mathrm{~b}$ depicts the declines of $R_{\text {eco }}$ and NEP with WSI and the corresponding changes of the ratios of autotrophic respiration to GPP $\left(R_{\mathrm{a}} / \mathrm{GPP}\right)$ and heterotrophic respiration to whole-ecosystem respiration $\left(R_{\mathrm{h}} / R_{\mathrm{eco}}\right)$. The $R_{\mathrm{a}} / \mathrm{GPP}$ ratio increased from 0.581 to 0.627 for a change of WSI from 
Table 1. Parameters of the linear ordinary least-square regression lines between the WSI in MPa day and components of the ecosystem yearly $\mathrm{C}$ budget and aboveground components of the productivity. $\alpha_{\mathrm{OLS}}$ is the slope of the $Y$ vs. $X$ relationship. GPP, $R_{\mathrm{eco}}$ and NEP are gross primary productivity, ecosystem respiration and net ecosystem productivity, respectively, in $\mathrm{gC}^{-2} \mathrm{yr}^{-1}$. The components of the aboveground productivity for leaves, reproductive effort and stem $\mathrm{ANPP}_{\text {leaf }}, \mathrm{ANPP}_{\text {reprod }}$ and $\mathrm{ANPP}_{\text {stem }}$ are also expressed in $\mathrm{g} \mathrm{C} \mathrm{m}^{-2} \mathrm{yr}^{-1}$.

\begin{tabular}{llllllr}
\hline$Y$ vs. $X$ & $\alpha_{\text {OLS }} \pm$ SE & $\beta_{\text {OLS }} \pm \mathrm{SE}$ & $r^{2}$ & $F$ & $p$ & $n$ \\
\hline GPP vs. WSI & $1.91 \pm 0.43$ & $1675 \pm 97.5$ & 0.72 & 20.1 & $0.0021^{* *}$ & 10 \\
$R_{\text {eco vs. WSI }}$ & $0.77 \pm 0.32$ & $1144 \pm 72.5$ & 0.42 & 5.8 & $0.042^{*}$ & 10 \\
$\mathrm{NEP}_{\text {vs. WSI }}$ & $1.15 \pm 0.20$ & $531.3 \pm 46.2$ & 0.80 & 32.2 & $0.0005^{* *}$ & 10 \\
$\mathrm{ANPP}_{\text {leaf }}(t)^{\circ}$ vs. WSI $(t-1)$ & $0.41 \pm 0.15$ & $233.0 \pm 34.6$ & 0.52 & 7.5 & $0.03^{*}$ & 9 \\
$\mathrm{ANPP}_{\text {leaf }}(t)^{\circ}$ vs. WSI $(t)$ & $-0.12 \pm 0.19$ & $116.1 \pm 43.6$ & 0.05 & 0.41 & $0.54 \mathrm{~ns}$ & 9 \\
$\mathrm{ANPP}_{\text {reprod }}$ vs. WSI & $0.10 \pm 0.04$ & $49.1 \pm 8.8$ & 0.48 & 7.2 & $0.027^{*}$ & 10 \\
$\mathrm{ANPP}_{\text {stem vs. WSI }}$ & $0.42 \pm 0.10$ & $162.9 \pm 22.5$ & 0.69 & 17.9 & $0.0029^{* *}$ & 10
\end{tabular}

${ }^{*}$ significant; ${ }^{* *}$ highly significant.

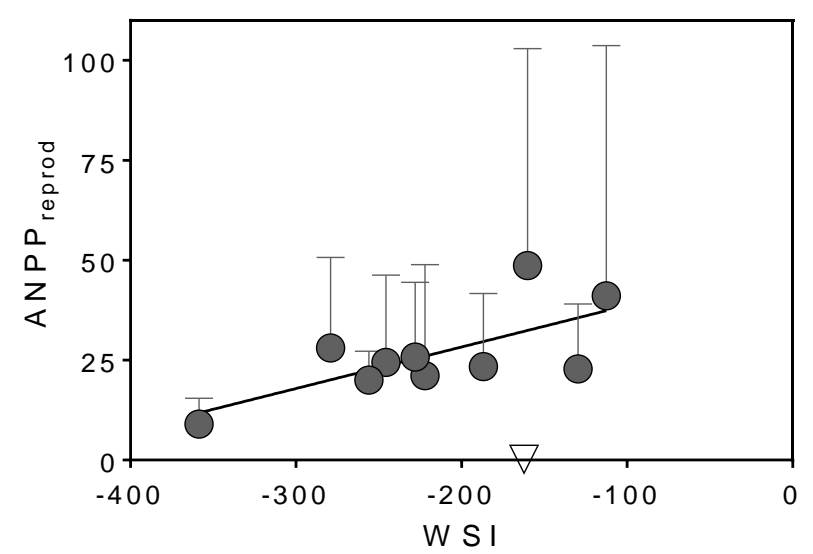

Figure 5. Ordinary least-square regression line between the WSI and the net productivity of the reproductive effort (flowers and fruits; error bars are standard deviation). WSI is expressed in $\mathrm{MPa}$ day and $\mathrm{ANPP}_{\text {reprod }}$ in $\mathrm{g} \mathrm{C} \mathrm{m}^{-2} \mathrm{yr}^{-1}$. Data from 2005 that were not used in the analysis were also plotted (empty triangle).

-100 to $-400 \mathrm{MPa}$ day. For the same decline in WSI, the ratio of $R_{\mathrm{h}} / R_{\text {eco }}$ increased from 0.192 to 0.321 , with $R_{\mathrm{h}}$ slightly increasing from 205.1 to $268.1 \mathrm{~g} \mathrm{C} \mathrm{m}^{-2} \mathrm{yr}^{-1}$.

\section{Discussion}

\subsection{Carbon-use efficiency in a Mediterranean coppice - management and drought-adaptation constraints on carbon allocation rules}

CUE, the ratio of net primary production (NPP) to gross primary production (GPP), describes the capacity of forests to assimilate $\mathrm{C}$ from the atmosphere into terrestrial biomass. CUE of forests has been assumed, by some authors, to be a constant value of $0.47 \pm 0.04$ (Gifford, 2003; Waring et al., 1998), which supposes that tree respiration is a constant fraction of GPP. Contrary to this assumption of con- stancy, substantial variations in CUE have been reported in forest ecosystems. Medlyn and Dewar (1999) demonstrated that CUE likely ranges between 0.31 and 0.59 , and a more recent synthesis by DeLucia et al. (2007) showed that the slope of the relationship between NPP and GPP (CUE) was 0.53 , ranging from 0.23 to 0.83 among forest types. CUE decreased with increasing age, and a substantial portion of the variation among forest types was caused by the ratio of leaf mass / total mass. For a ratio of leaf mass / total mass of 0.03 , corresponding to our $Q$. ilex forest, DeLucia et al. (2007) predicted a CUE of 0.38 , similar to the mean of 0.40 obtained here, and the same value that Oechel and Lawrence (1981) obtained for Californian and Chilean shrub and tree species. With the process-based simulation model Gotilwa applied to a $Q$. ilex coppice in northeastern Spain, Gracia et al. (1999) predicted a CUE of 0.41. In contrast, Luyssaert et al. (2007) derived a surprisingly high value of 0.54 from a global database for their so-called "Mediterranean warm evergreen" biome (Table 2).

The low ecosystem CUE observed at our site (around 0.40) could be due to the ancient management of the ecosystem as a coppice. The large belowground biomass and respiratory maintenance costs associated with this management system may alter $\mathrm{C}$ use rules and constrain CUE compared to more productive high forests (Salomón et al., 2013). Furthermore, relatively high $R_{\text {aa }}$ (see below) could be associated with the role of aboveground organs in storing nitrogen and nonstructural carbohydrates. 1-year old leaves act as reservoirs contributing to spring shoot growth (Cherbuy et al., 2001), while stumps and stems contain a large amount of parenchyma, helping the tree to resprout after perturbations. Accurately quantifying the relative importance of respiratory sources is an important step towards understanding the whole $\mathrm{C}$ budget. Under the steady-state assumption of Eq. (9) (Raich and Nadelhoffer, 1989), our values of GPP, ANPP and $R_{\text {aa }}$ resulted in $\mathrm{TBCF}=670 \mathrm{~g} \mathrm{C} \mathrm{m}^{-2} \mathrm{yr}^{-1}$. $R_{\text {aa }}$ was $460 \mathrm{~g} \mathrm{C} \mathrm{m}^{-2} \mathrm{yr}^{-1}$, a value estimated from leaf respiration and stem $\mathrm{CO}_{2}$ efflux measurements made at our 
Table 2. Literature values of carbon use efficiencies (CUE) for a broad range of forests.

\begin{tabular}{lll}
\hline Reference & Vegetation & CUE \\
\hline This work & Quercus ilex coppice & $0.40(0.37-0.42)$ \\
Oechel and Lawrence (1981) & MTE spp. & 0.38 \\
Waring et al. (1998) & Broad range of forests (BRFs) & $0.47 \pm 0.04$ \\
Medlyn and Dewar (1999) & BRFs & $0.31-0.59$ \\
Gracia et al. (1999) & Quercus ilex coppice & 0.41 \\
De Lucia et al. (2007) & BRFs & $0.53(0.23-0.83)$ \\
Luyssaert et al. (2007) & Mediterranean warm evergreen & 0.54 \\
Litton and Giardina (2008) & BRFs & 0.43 \\
Luyssaert et al. (2009) & Temp. and boreal forests & $0.51 \pm 0.02$ \\
Piao et al. (2010) & BRFs (MAT $\left.=13^{\circ} \mathrm{C}\right)$ & 0.475 \\
Vica et al. (2012) & BRFs with low-nutrient availability & $0.42 \pm 0.02$ \\
\hline
\end{tabular}

site and upscaled to the stand (Rodríguez-Calcerrada et al., 2011, 2014). Applying the same TBCF approach to the Misson et al. (2010) data of soil respiration for the wet 2004 year yielded a TBCF of $630 \mathrm{~g} \mathrm{C} \mathrm{m}^{-2} \mathrm{yr}^{-1}$. With our estimate of $\mathrm{BNPP}=270 \mathrm{~g} \mathrm{C} \mathrm{m}^{-2} \mathrm{yr}^{-1}$, the $R_{\mathrm{ab}}$ ranged between 360 and $400 \mathrm{~g} \mathrm{C} \mathrm{m}^{-2} \mathrm{yr}^{-1}$. Finally, we could deduct an $R_{\mathrm{h}}$ ranging between 210 and $230 \mathrm{~g} \mathrm{C} \mathrm{m}^{-2} \mathrm{yr}^{-1}$ by summing the three respiration components to reach the wholeecosystem respiration $R_{\text {eco }}$. For comparison, the metaanalysis of Litton and Giardina (2008) report a TBCF of $705 \mathrm{~g} \mathrm{C} \mathrm{m}^{-2} \mathrm{yr}^{-1}$ and a BNPP of $334 \mathrm{~g} \mathrm{C} \mathrm{m}^{-2} \mathrm{yr}^{-1}$, and Rodeghiero and Cescatti (2006) measured, in a more mesic Quercus ilex coppice in which the soil respiration is very high (1079 $\mathrm{g} \mathrm{C} \mathrm{m}^{-2} \mathrm{yr}^{-1}$ ), a TBCF of $564 \mathrm{~g} \mathrm{C} \mathrm{m}^{-2} \mathrm{yr}^{-1}$ with the two belowground respiration components $R_{\mathrm{ab}}$ and $R_{\mathrm{h}}$ being equal.

\subsection{Sensitivity of carbon use and partitioning to between-year variation in water limitation}

To characterize year-to-year variations in drought severity, we used a long-term cumulated water stress index: the WSI. This concept likely originated in Schulze et al. (1980a, b), who related changes in normalized maximal assimilation rates and daily carbon gain with the sum of water stress obtained by cumulating daily pre-dawn water potentials from the day of the last rainfall to the day under consideration. Later, Wullschleger and Hanson (2006) did the same with transpiration rates from trees growing in a throughfall displacement experiment. This cumulated water stress, called water-stress integral, or WSI by Myers (1988), has been applied to predict growth processes occurring at longer timescales, such as canopy development, litter fall dynamic and tree radial growth (Benson et al., 1992; Raison et al., 1992a, b). In our study, we demonstrated that WSI was significantly related to the current year reproductive effort, secondary growth and all ecosystem C fluxes (see also Arneth et al., 1998), and that it was useful in explaining how the previ- ous year's drought limitation affected the leaf production in the subsequent year.

GPP, $R_{\text {eco }}$ and NEP were largely impacted by water limitation. The decline of GPP with drought has been observed in our site at different time and space scales. At a seasonal timescale, Limousin et al. (2010) intensively discussed how leaf photosynthetic limitations were related to predawn water potential. At a daily timescale, GPP estimated from eddy correlation fluxes was related to predawn water potential (Rambal et al., 2003). The ANPP components have also been shown to be impacted by drought severity, with a hierarchy of responses going from the more affected - the stem - to the less affected - the leaves (Table 1). The larger sensitivity of stem growth validates the hypothesis of the Forest-BGC model (Hoff et al., 2002) in which trees allocate $C$ first to leaves and fine roots, for maximizing productivity while minimizing water stress, and then to stems; and then to stems which appear as an end product built with the remaining $\mathrm{C}$. The reproductive effort also declined significantly with increasing drought, although it represented a smaller $\mathrm{C}$ use. Acorn production - the larger component of reproduction - has been shown to be influenced by water availability during the fruiting process, in particular during the initial (spring) and advanced (summer) stages of the maturation cycle (Pérez-Ramos et al., 2010).

The leaf production was not related to the current year's WSI but to the previous year's WSI. Limousin et al. (2012) observed that, in $Q$. ilex, the leaf litterfall was also positively correlated with the previous year's WSI so that more leaves were shed and replaced following wet years than following dry years. This phenomenon might be explained by the cost-benefit hypothesis (Chabot and Hicks, 1982; Kikuzawa, 1991): if the leaf carbon assimilation is reduced by water limitation during a dry year, the leaf life span should increase for the leaf lifetime carbon gain to pay back the leaf construction cost, and thus fewer new leaves need to be produced to maintain the LAI. This results in an alternation of years with high leaf production / shedding following wet years and years of opposite characteristics, as commonly observed in 

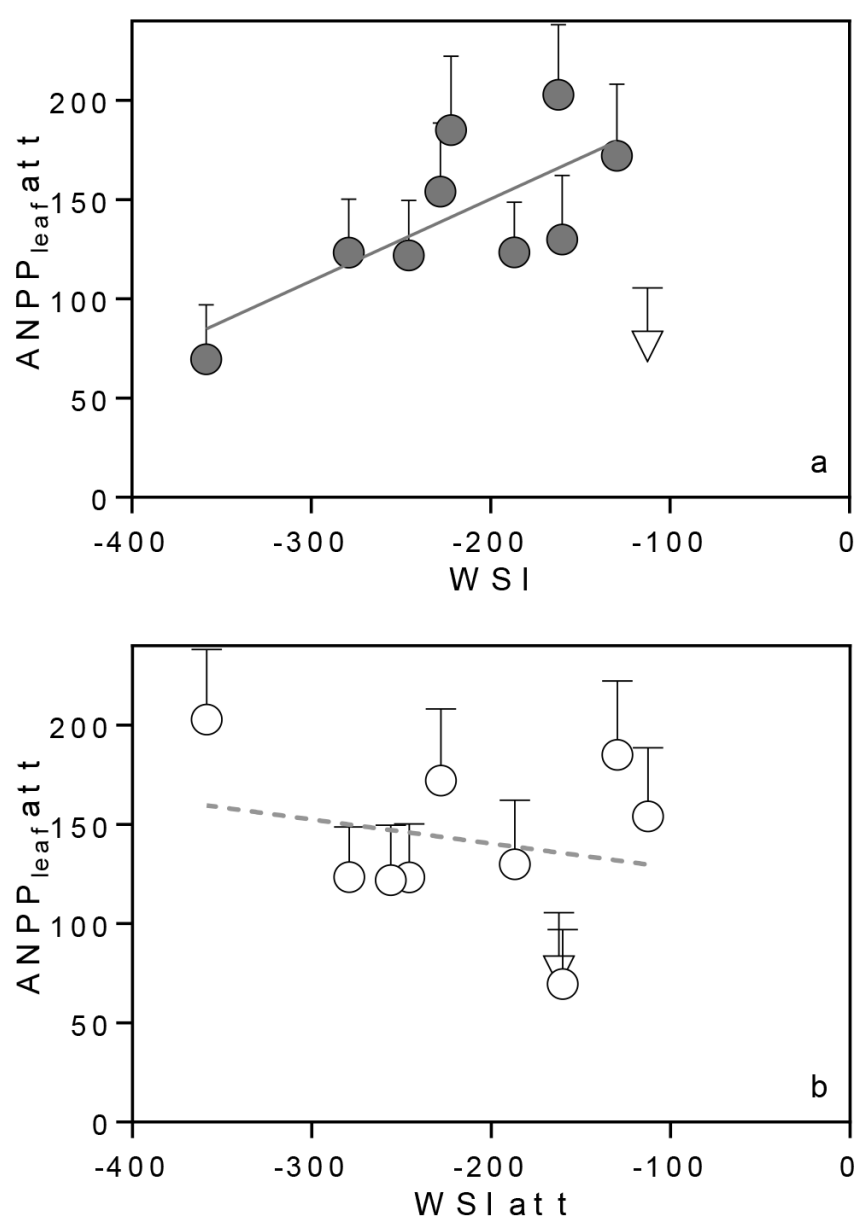

Figure 6. Ordinary least-square regression lines between the aboveground net primary productivity of leaves of the current year and (a) the WSI of the previous year (dark grey circle and standard deviation), and (b) the WSI of the current year (empty circle and standard deviation). WSI is expressed in MPa day and ANPP leaf in $\mathrm{g} \mathrm{C} \mathrm{m}^{-2} \mathrm{yr}^{-1}$. Data from 2005 that were not used in the analysis were also plotted (empty triangle).

evergreen species and, in particular, $Q$. ilex (MontserratMarti et al., 2009; Ogaya and Penuelas, 2006; Rapp, 1969). Such a mechanism may also contribute to maintain the water transport capacity of $Q$. ilex under long-lasting drought, as proposed by Martin-StPaul et al. (2013). Current-year drought causes GPP and, less so, NPP to decline, so that CUE declines slightly. In a wet year following a drier one, CUE could decline because ANPP $_{\text {stem }}$ would be ruled by current climate and would be high, corresponding to a wet year, while leaves would be produced in fewer amounts due to the 1-year-lag effect of drought on leaf production, and CUE could decline. Further research could be necessary to quantify such a carry-over effect on CUE. Perhaps the strategy of $Q$. ilex to buffer the hydraulic system from climatic extremes has a penalty on CUE.
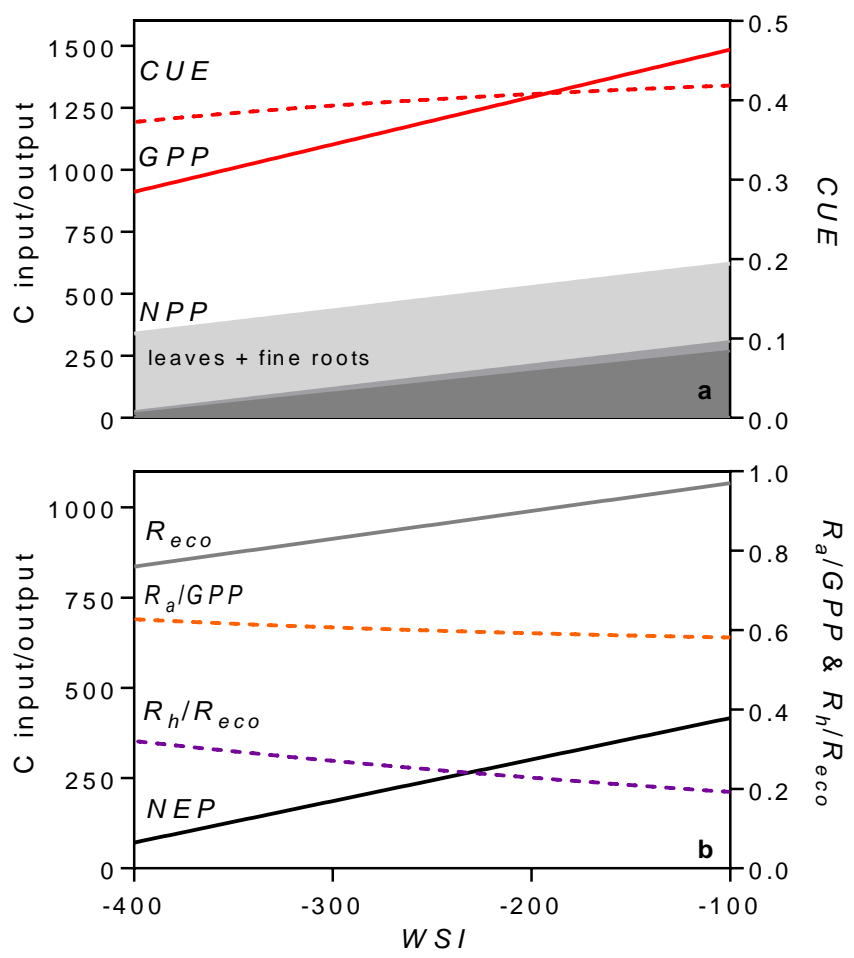

Figure 7. (a) Change in the partition of gross primary productivity (GPP), expressed in $\mathrm{g} \mathrm{C} \mathrm{m}^{-2} \mathrm{yr}^{-1}$, with increasing drought intensity quantified by the WSI in MPa day. The red line displays the decline of GPP with decreasing WSI. The net primary productivity (NPP) components are perennial aboveground + belowground parts (dark grey), reproductive effort (flowers and fruits; medium grey) and leaves and fine roots (light grey), all expressed in $\mathrm{g} \mathrm{C} \mathrm{m}^{-2} \mathrm{yr}^{-1}$. The dashed red curve is for the CUE. (b) Change in ecosystem respiration ( $R_{\text {eco }}$, grey line) and net ecosystem productivity (NEP) (dark line), both in $\mathrm{g} \mathrm{C} \mathrm{m}^{-2} \mathrm{yr}^{-1}$, with increasing drought intensity (WSI). The dashed orange line is for the $R_{\mathrm{a}} /$ GPP ratio and the dashed purple line for the $R_{\mathrm{h}} / R_{\text {eco }}$ ratio.

Based on the responses to drought of the different compartments and on the assumptions stated above (see Sect. 2), we calculated the yearly CUE response to drought (Fig. 7a). CUE slightly decreased with drought from 0.419 at WSI $=-100 \mathrm{MPa}$ day to 0.373 at WSI $=-400 \mathrm{MPa}$ day. Interestingly, CUE declined at a slower rate than GPP and NPP in response to water deficit (Fig. 7a). Maseyk et al. (2008) reported a constant CUE of 0.4 in a Pinus halepensis forest growing in a semi-arid Mediterranean-type climate and proposed that acclimation of maintenance respiration to dry conditions could help in maintaining CUE and keeping productivity relatively high under such water limited climate. Recent studies at our site showed that respiration rates declined exponentially in both leaves and stems as tree water availability decreased through summer months (RodríguezCalcerrada et al., 2011, 2014). Based on the relationships between leaf/shoot predawn water potential and leaf/stem respiration, we calculated that stem and foliage $\mathrm{CO}_{2}$ efflux 
declined by 4.7 and $7.1 \%$, respectively, for an increase of drought severity of WSI $=100 \mathrm{MPa}$ day. Altogether, acclimation of leaf, stem and root respiration to plant water deficit buffers NPP sensitivity to drought and contributes to keeping CUE relatively constant across years of widely different rainfall and vegetation stress. The ultimate reasons for such reduction in respiration rates are still unclear, but it appears that reduced demand of respiratory products from growth and maintenance processes may cause a down-regulation of mitochondrial activity (Atkin and Macherel, 2009).

Besides reductions in autotrophic respiration, changes in $R_{\mathrm{h}}$ contribute to complicating our understanding of the impact of drought on the whole-ecosystem $\mathrm{C}$ sink strength. In trees, acclimation refers to strictly physiological processes, while soils changes in $R_{\mathrm{h}}$ refer to ecosystem-level phenomenon potentially driven by multiple mechanisms, including substrate depletion, changing microbial community composition and physiological changes. Substantial questions remain about its response to soil water status, the interactions with substrate quality, and the role of the top soil dryingrewetting cycles (Wei et al., 2010). The course of soil water content at timescales shorter than the season is not necessarily correlated to the WSI. In Mediterranean-type ecosystems, $R_{\mathrm{h}}$ is likely more influenced by an unpredictable supply of substrate to the rhizosphere than by changes in the microbial community or its efficiency (Curiel Yuste et al., 2014). Finally, we suggest, as Hopkins et al. (2013) did, that substrate availability sensu lato, including GPP and storage of nonstructural $\mathrm{C}$ pool (neglected here), may be the ultimate driver of the two respiration fluxes.

\section{Conclusions}

Comparative measures of ecosystem fluxes and production components across $11 \mathrm{yr}$ of contrasting water limitations in a Q. ilex coppice help to better understand how Mediterraneantype forest ecosystems will respond to the ongoing climate change and to better project future $\mathrm{C}$ sequestration capacity.

We observed a clear effect of water availability in limiting all the ecosystem fluxes GPP, $R_{\text {eco }}$ and NEP, and that the drought-induced decline in $R_{\text {eco }}$ dampens the decline of the ecosystem $C$ sequestration under drought conditions. In parallel, all the growth components were found to be affected by water limitation, with a partition of GPP into tissues that tends to minimize the negative impacts of drought on growth. An important result is that all the changes followed the same trajectory as water stress varied over a large range of conditions, from a wet year to a dry year occurring only once every 67 yr. We did not observe any tipping point or discontinuity in the $\mathrm{C}$ partitioning pattern. On average, only $40 \%$ of the carbon assimilated as gross photosynthesis was used to construct new tissues, with the remaining $60 \%$ being respired back to the atmosphere as autotrophic respiration. This low ecosystem CUE could be inherited from the ancient manage- ment of the ecosystem as a coppice and its large amount of standing belowground biomass.

There are several ecological issues that question the values of the estimated $\mathrm{C}$ fluxes and their changes in increasing drought severity. It appeared, in our case, that autotrophic respiration by trees and heterotrophic respiration by soil microorganisms are primarily responsible for mediating the larger part of the carbon exchanges between the biosphere and atmosphere. Climate changes and projected increasing dryness have the potential to influence the activity of trees regulating exchanges among the carbon pools. Functional "down-regulation" or acclimation of plant respiration could reduce the respiratory autotrophic loss of ecosystems, but, unlike plant components, the existence of this phenomenon in heterotrophic respiration remains more controversial (Harmon et al., 2011; Wieder et al., 2013). Current models can simulate GPP relationships with autotrophic fluxes in a warmer environment (Piao et al., 2010; Wythers et al., 2013), yet the parameterization of models able to capture the apparent respiratory acclimation of both $R_{\mathrm{a}}$ and $R_{\mathrm{h}}$ to water limitation of ecosystems is an emerging challenge for the modeling and flux research communities. We suggest that both communities adopt a bottom-up approach to advance our understanding at tissue, tree and ecosystem scales to increasingly larger timescales and space scales. 


\section{Appendix A}

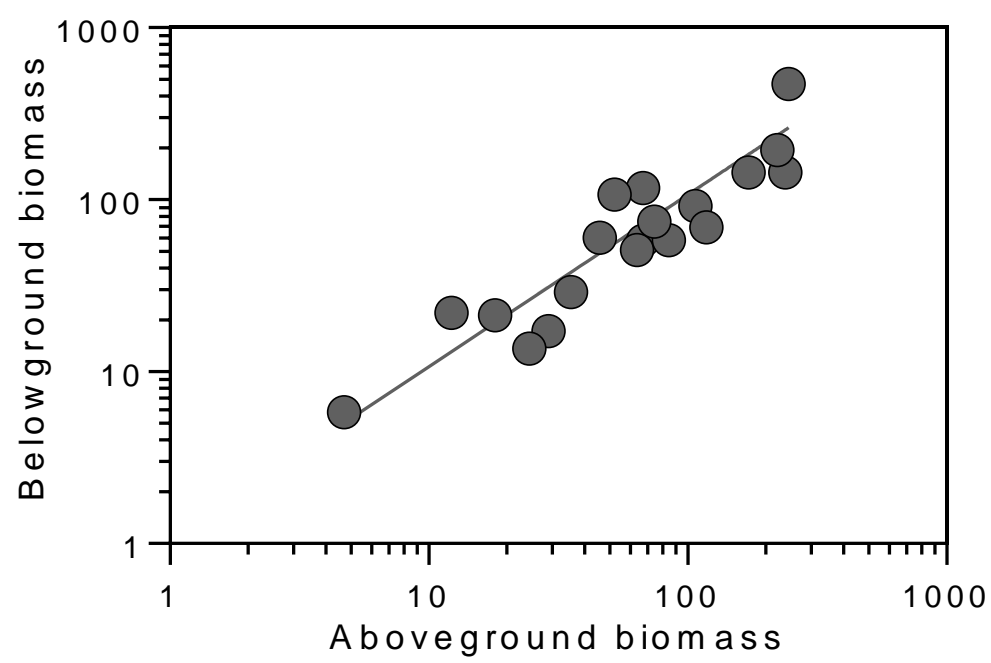

Figure A1. Relationship between aboveground perennial biomass (g Dry Matter) and the corresponding belowground biomass (g Dry Matter). The belowground biomass is the sum of biomass values for root crown, roots greater than $5 \mathrm{~cm}$ and roots ranging from 1 to $5 \mathrm{~cm}$ in diameter.

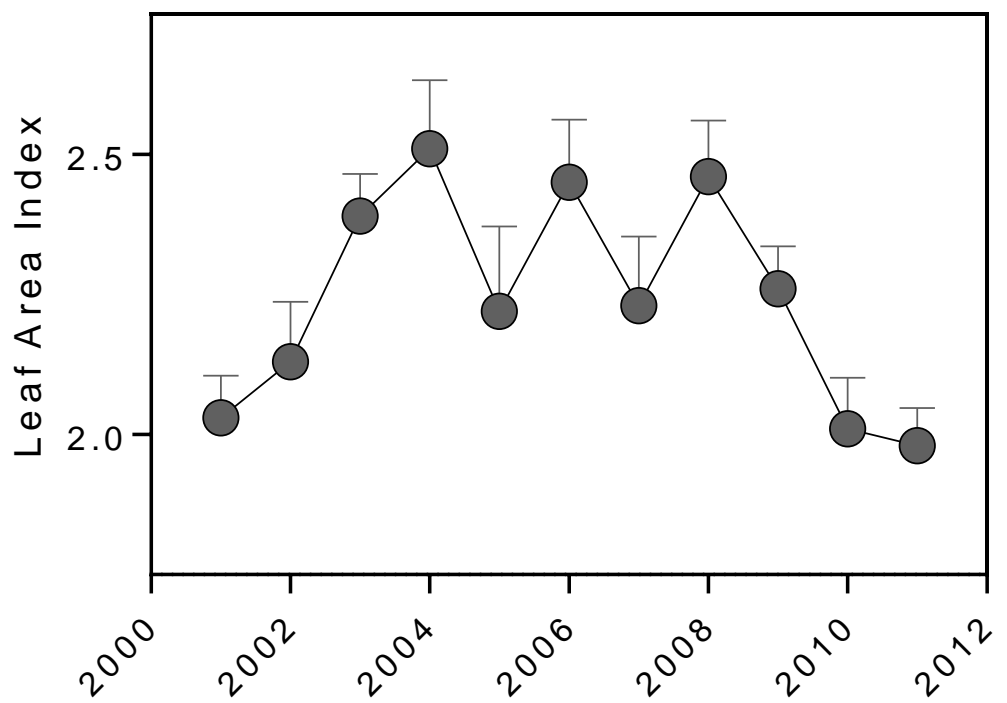

Figure A2. Time course of the peak LAI derived from continuous measurements of half-hourly $f_{\text {APAR }}$ between 11.00 a.m. and 1.00 p.m. from DOY 205 to 225 . The stem area index (SAI) was estimated by image processing of hemispheric photography and assumed constant for the whole period and equal to 0.5 . The relationship between leaf area index and water stress integral (WSI) is statistically non-significant. 
Acknowledgements. A doctoral research grant was provided by the French Environment and Energy Management Agency (ADEME) to M. Lempereur. The projects MIND (no. EVK2-CT2002-000158), DROUGHT+ (no. ANR-06-VULN-003-01) and CARBO-Extreme (no. FP7-ENV-2008-1-226701) contributed in partly funding this research. The authors declare no conflict of interest in relation with this work.

Edited by: K. Guan

\section{References}

Ackerly, D.: Functional strategies of chaparral shrubs in relation to seasonal water deficit and disturbance, Ecol. Monogr., 74, 25-44, 2004.

Allard, V., Ourcival, J. M., Rambal, S., Joffre, R., and Rocheteau, A.: Seasonal and annual variation of carbon exchange in an evergreen Mediterranean forest in southern France, Glob. Change Biol., 14, 714-725, 2008.

Arneth, A., Kelliher, F., McSeveny, T., and Byers, J.: Net ecosystem productivity, net primary productivity and ecosystem carbon sequestration in a Pinus radiata plantation subject to soil water deficit, Tree Physiol., 18, 785-793, 1998.

Atkin, O. K. and Macherel, D.: The crucial role of plant mitochondria in orchestrating drought tolerance, Ann. Botany, 103, 581597, 2009.

Aubinet, M., Grelle, A., Ibrom, A., Rannik, U., Noncrieff, J., Foken, T., Kowalski, A. S., Martin, P. H., Berbigier, P., Bernhofer, C., Clement, R., Elbers, J., Granier, A., Grunwald, T., Morgenstern, K., Pilegaard, K., Rebmann, C., Snijders, W., Valentini, R., and Vesala, T.: Estimates of the annual net carbon and water exchange of forests: The EUROFLUX methodology, Adv. Ecol. Res., 30, 113-175, 2000.

Beer, C., Reichstein, M., Tomelleri, E., Ciais, P., Jung, M., Carvalhais, N., Rödenbeck, C., Arain, M. A., Baldocchi, D., Bonan, G. B., Bondeau, A., Cescatti, A., Lasslop, G., Lindroth, A., Lomas, M., Luyssaert, S., Margolis, H., Oleson, K. W., Roupsard, O., Veenendaal, E., Viovy, N., Williams, C., Woodward, F. I., and Papale, D.: Terrestrial gross carbon dioxide uptake: Global distribution and covariation with climate, Science, 329, 834-838, 2010.

Benson, M., Myers, B., and Raison, R.: Dynamics of stem growth of Pinus radiata as affected by water and nitrogen supply, For. Ecol. Manage., 52, 117-137, 1992.

Bonan, G. B.: Forests and climate change: forcings, feedbacks, and the climate benefits of forests, Science, 320, 1444-1449, 2008.

Brouwer, R.: Distribution of dry matter in the plant, Neth. J. Agric. Sci., 10, 361-376, 1962.

Campbell, G. S.: Soil physics with basic: Transport models for soilplant systems, Elsevier, 1985.

Canadell, J. and Roda, F.: Root biomass of Quercus ilex in a montane Mediterranean forest, Can. J. For. Res., 21, 1771-1778, 1991.

Chabot, B. F. and Hicks, D. J.: The ecology of leaf life spans, Ann. Rev. Ecol. System., 13, 229-259, 1982.

Cherbuy, B., Joffre, R., Gillon, D., and Rambal, S.: Internal remobilization of carbohydrates, lipids, nitrogen and phosphorus in the Mediterranean evergreen oak Quercus ilex, Tree Physiol., 21, 9-17, 2001.

Clarke, P. J., Lawes, M. J., and Midgley, J. J.: Resprouting as a key functional trait in woody plants-challenges to developing new organizing principles, New Phytol., 188, 651-654, 2010.

Curiel Yuste, J., Fernandez-Gonzalez, A., Fernandez-Lopez, M., Ogaya, R., Penuelas, J., Sardans, J., and Lloret, F.: Strong functional stability of soil microbial communities under semiarid Mediterranean conditions and subjected to long-term shifts in baseline precipitation, Soil Biol. Biochem., 69, 223-233, 2014.

DeLucia, E. H., Drake, J. E., Thomas, R. B., and Gonzalez-Meler, M.: Forest carbon use efficiency: is respiration a constant fraction of gross primary production?, Glob. Change Biol., 13, 11571167, 2007.

Djema, A.: Cuantificación de la biomasa y mineralomasa subterránea de un bosque de Quercus ilex L., MSc thesis, Instituto Agronómico Mediterráneo, Zaragoza, España, 78 pp., 1995.

Eckardt, F., Heim, G., Methy, M., and Sauvezon, R.: Interception de l'énergie rayonnante, échanges gazeux et croissance dans une forêt méditerranéenne à feuillage persistant (Quercetum ilicis), Photosynthetica, 9, 145-156, 1975.

Fatichi, S., Leuzinger, S., and Körner, C.: Moving beyond photosynthesis: from carbon source to sink-driven vegetation modeling, New Phytol., 2013.

Franklin, O., Johansson, J., Dewar, R. C., Dieckmann, U., McMurtrie, R. E., Brännström, Å., and Dybzinski, R.: Modeling carbon allocation in trees: a search for principles, Tree Physiol., 32, 648666, 2012.

Gifford, R. M.: Plant respiration in productivity models: conceptualisation, representation and issues for global terrestrial carboncycle research, Functional Plant Biology, 30, 171-186, 2003.

Giorgi, F.: Climate change hot-spots, Geophys. Res. Lett., 33, L08707, doi:0.1029/2006GL025734, 2006.

Gracia, C. A., Tello, E., Sabaté, S., and Bellot, J.: GOTILWA: An integrated model of water dynamics and forest growth, in: Ecology of Mediterranean evergreen oak forests, Springer, 163-179, 1999.

Grote, R., Lavoir, A.-V., Rambal, S., Staudt, M., Zimmer, I., and Schnitzler, J.-P.: Modelling the drought impact on monoterpene fluxes from an evergreen Mediterranean forest canopy, Oecologia, 160, 213-223, 2009.

Grünzweig, J., Lin, T., Rotenberg, E., Schwartz, A., and Yakir, D.: Carbon sequestration in arid-land forest, Glob. Change Biol., 9, 791-799, 2003.

Harmon, M. E., Bond-Lamberty, B., Tang, J., and Vargas, R.: Heterotrophic respiration in disturbed forests: A review with examples from North America, J. Geophys. Res. Biogeosci. (20052012), 116, G00K04, doi:10.1029/2010JG001495, 2011.

Hoerling, M., Eischeid, J., Perlwitz, J., Quan, X., Zhang, T., and Pegion, P.: On the increased frequency of Mediterranean drought, J. Climate, 25, 2146-2161, 2011.

Hoff, C. and Rambal, S.: An examination of the interaction between climate, soil and leaf area index in a Quercus ilex ecosystem, Ann. For. Sci., 60, 153-161, 2003.

Hoff, C., Rambal, S., and Joffre, R.: Simulating carbon and water flows and growth in a Mediterranean evergreen Quercus ilex coppice using the FOREST-BGC model, For. Ecol. Manage., 164, 121-136, 2002. 
Hopkins, F., Gonzalez-Meler, M. A., Flower, C. E., Lynch, D. J., Czimczik, C., Tang, J., and Subke, J. A.: Ecosystem-level controls on root-rhizosphere respiration, New Phytol., 199, 339-351, 2013.

Iwasa, Y. and Kubo, T.: Optimal size of storage for recovery after unpredictable disturbances, Evolut. Ecol., 11, 41-65, 1997.

Jackson, R. B., Mooney, H., and Schulze, E.-D.: A global budget for fine root biomass, surface area, and nutrient contents, Proc. Natl. Acad. Sci., 94, 7362-7366, 1997.

Jaeger, E. B. and Seneviratne, S. I.: Impact of soil moistureatmosphere coupling on European climate extremes and trends in a regional climate model, Clim. Dynam., 36, 1919-1939, 2011.

Kikuzawa, K.: A cost-benefit analysis of leaf habit and leaf longevity of trees and their geographical pattern, American Naturalist, 138, 1250-1263, 1991.

Kjellström, E., Thejll, P., Rummukainen, M., Christensen, J. H., Boberg, F., Christensen, O. B., and Maule, C. F.: Emerging regional climate change signals for Europe under varying largescale circulation conditions, Clim. Res., 56, 103-119, 2013.

Leuzinger, S. and Quinn Thomas, R.: How do we improve Earth system models? Integrating Earth system models, ecosystem models, experiments and long-term data, New Phytol., 191, 1518, 2011.

Limousin, J.-M., Longepierre, D., Huc, R., and Rambal, S.: Change in hydraulic traits of Mediterranean Quercus ilex subjected to long-term throughfall exclusion, Tree Physiol., 30, 1026-1036, 2010.

Limousin, J. M., Rambal, S., Ourcival, J. M., Rodriguez-Calcerrada, J., Perez-Ramos, I. M., Rodriguez-Cortina, R., Misson, L., and Joffre, R.: Morphological and phenological shoot plasticity in a Mediterranean evergreen oak facing long-term increased drought, Oecologia, 169, 565-577, 2012.

Litton, C. and Giardina, C.: Below-ground carbon flux and partitioning: Global patterns and response to temperature, Funct. Ecol., 22, 941-954, 2008.

Lloret, F., Siscart, D., and Dalmases, C.: Canopy recovery after drought dieback in holm-oak Mediterranean forests of Catalonia (NE Spain), Glob. Change Biol., 10, 2092-2099, 2004.

López, B., Sabaté, S., and Gracia, C.: Annual and seasonal changes in fine root biomass of a Quercus ilex L. forest, Plant Soil, 230, 125-134, 2001a.

López, B., Sabaté, S., and Gracia, C. A.: Vertical distribution of fine root density, length density, area index and mean diameter in a Quercus ilex forest, Tree Physiol., 21, 555-560, 2001b.

López-Moreno, J. I., Vicente-Serrano, S. M., Gimeno, L., and Nieto, R.: Stability of the seasonal distribution of precipitation in the Mediterranean region: Observations since 1950 and projections for the 21st century, Geophys. Res. Lett., 36, L10703, 10.1029/2009GL037956, 2009.

Luo, Y., Melillo, J., Niu, S., Beier, C., Clark, J. S., Classen, A. T., Davidson, E., Dukes, J. S., Evans, R. D., Field, C. B., Czimczik, C. I., Keller, M., Kimball, B. A., Kueppers, L. M., Norby, R. J., Pelini, S. L., Pendall, E., Rastetter, E., Six, J., Smith, M., Tjoelker, M. G., and Torn, M. S.: Coordinated approaches to quantify long-term ecosystem dynamics in response to global change, Glob. Change Biol., 17, 843-854, 2011.

Luyssaert, S., Inglima, I., Jung, M., Richardson, A. D., Reichstein, M., Papale, D., Piao, S. L., Schulze, E. D., Wingate, L., Matteucci, G., Aragao, L., Aubinet, M., Beer, C., Bernhofer, C.,
Black, K. G., Bonal, D., Bonnefond, J. M., Chambers, J., Ciais, P., Cook, B., Davis, K. J., Dolman, A. J., Gielen, B., Goulden, M., Grace, J., Granier, A., Grelle, A., Griffis, T., GrÜNwald, T., Guidolotti, G., Hanson, P. J., Harding, R., Hollinger, D. Y., Hutyra, L. R., Kolari, P., Kruijt, B., Kutsch, W., Lagergren, F., Laurila, T., Law, B. E., Le Maire, G., Lindroth, A., Loustau, D., Malhi, Y., Mateus, J., Migliavacca, M., Misson, L., Montagnani, L., Moncrieff, J., Moors, E., Munger, J. W., Nikinmaa, E., Ollinger, S. V., Pita, G., Rebmann, C., Roupsard, O., Saigusa, N., Sanz, M. J., Seufert, G., Sierra, C., Smith, M. L., Tang, J., Valentini, R., Vesala, T., and Janssens, I. A.: $\mathrm{CO}_{2}$ balance of boreal, temperate, and tropical forests derived from a global database, Glob. Change Biol., 13, 2509-2537, 2007.

Mäkelä, A.: Implications of the pipe model theory on dry matter partitioning and height growth in trees, J. Theoret. Biol., 123, 103-120, 1986.

Martin-StPaul, N. K., Limousin, J. M., Vogt-Schilb, H., RodríguezCalcerrada, J., Rambal, S., Longepierre, D., and Misson, L.: The temporal response to drought in a Mediterranean evergreen tree: comparing a regional precipitation gradient and a throughfall exclusion experiment, Glob. Change Biol., 19, 2413-2426, 2013.

Maseyk, K., Grünzweig, J. M., Rotenberg, E., and Yakir, D.: Respiration acclimation contributes to high carbon-use efficiency in a seasonally dry pine forest, Glob. Change Biol., 14, 1553-1567, 2008.

Medlyn, B. and Dewar, R.: Comment on the article by RH Waring, JJ Landsberg and M. Williams relating net primar production to gross primary production, Tree Physiol., 19, 137-138, 1999.

Misson, L., Rocheteau, A., Rambal, S., Ourcival, J.-M., Limousin, J.-M., and Rodriguez, R.: Functional changes in the control of carbon fluxes after 3 years of increased drought in a Mediterranean evergreen forest?, Glob. Change Biol., 16, 2461-2475, 2010.

Misson, L., Degueldre, D., Collin, C., Rodriguez, R., Rocheteau, A., Ourcival, J.-M., and Rambal, S.: Phenological responses to extreme droughts in a Mediterranean forest, Glob. Change Biol., 17, 1036-1048, 2011.

Montserrat-Marti, G., Camarero, J. J., Palacio, S., Perez-Rontome, C., Milla, R., Albuixech, J., and Maestro, M.: Summer-drought constrains the phenology and growth of two coexisting Mediterranean oaks with contrasting leaf habit: implications for their persistence and reproduction, Trees-Struct. Funct., 23, 787-799, 2009.

Myers, B. J.: Water stress integral - a link between short-term stress and long-term growth, Tree Physiol., 4, 315-323, 1988.

Oechel, W. and Lawrence, W.: Carbon allocation and utilization, in: Resource Use by Chaparral and Matorral, edited by: Miller, P. C., Ecological Studies, Springer New York, 185-235, 1981.

Ogaya, R. and Penuelas, J.: Contrasting foliar responses to drought in Quercus ilex and Phillyrea latifolia, Biol. Plant., 50, 373-382, 2006.

Papale, D.: Towards a standardized processing of Net Ecosystem Exchange measured with eddy covariance technique: algorithms and uncertainty estimation, Biogeosciences, 3, 571-583, doi:10.5194/bg-3-571-2006, 2006.

Pérez-Ramos, I. M., Ourcival, J. M., Limousin, J. M., and Rambal, S.: Mast seeding under increasing drought: results from a longterm data set and from a rainfall exclusion experiment, Ecology, 91, 3057-3068, 10.1890/09-2313.1, 2010. 
Piao, S., Luyssaert, S., Ciais, P., Janssens, I. A., Chen, A., Cao, C., Fang, J., Friedlingstein, P., Luo, Y., and Wang, S.: Forest annual carbon cost: a global-scale analysis of autotrophic respiration, Ecology, 91, 652-661, 2010.

Quézel, P. and Médail, F.: Ecologie et biogéographie des forêts du bassin méditerranéen, Elsevier, Paris, France, 571 pp., 2003.

Raich, J. and Nadelhoffer, K.: Belowground carbon allocation in forest ecosystems: global trends, Ecology, 70, 1346-1354, 1989.

Raison, R., Khanna, P., Benson, M., Myers, B., McMurtrie, R., and Lang, A.: Dynamics of Pinus radiata foliage in relation to water and nitrogen stress: II. Needle loss and temporal changes in total foliage mass, For. Ecol. Manage., 52, 159-178, 1992a.

Raison, R., Myers, B., and Benson, M.: Dynamics ofPinus radiata foliage in relation to water and nitrogen stress: I. Needle production and properties, For. Ecol. Manage., 52, 139-158, 1992b.

Rambal, S.: Les transferts d'eau dans le systeme sol-plante en region mediterraneenne karstique: une approche hierarchique, Paris 11, 1990.

Rambal, S.: The differential role of mechanisms for drought resistance in a Mediterranean evergreen shrub: a simulation approach, Plant, Cell \& Environment, 16, 35-44, 1993.

Rambal, S.: Le paradoxe hydrologique des écosystèmes méditerranéens, Annales de la Société d'Horticulture et d'Histoire Naturelle de l'Hérault, 61-67, 2011.

Rambal, S. and Debussche, G.: Water balance of Mediterranean ecosystems under a changing climate, in: Global change and Mediterranean-type ecosystems, Springer, 386-407, 1995.

Rambal, S., Damesin, C., Joffre, R., Méthy, M., and Seen, D. L.: Optimization of carbon gain in canopies of Mediterranean evergreen oaks, Annales des sciences forestières, 547-560, 1996.

Rambal, S., Ourcival, J. M., Joffre, R., Mouillot, F., Nouvellon, Y., Reichstein, M., and Rocheteau, A.: Drought controls over conductance and assimilation of a Mediterranean evergreen ecosystem: scaling from leaf to canopy, Glob. Change Biol., 9, 1813$1824,2003$.

Rambal, S., Joffre, R., Ourcival, J., Cavender-Bares, J., and Rocheteau, A.: The growth respiration component in eddy $\mathrm{CO} 2$ flux from a Quercus ilex mediterranean forest, Glob. Change Biol., 10, 1460-1469, 2004.

Rapp, M.: Production de litière et apport au sol d'éléments minéraux dans deux écosystèmes méditerranéens: la forêt de Quercus ilex L. et la garrigue de Quercus coccifera L., Oecol. Plant., 4, 377-410, 1969.

Reichstein, M., Falge, E., Baldocchi, D., Papale, D., Aubinet, M., Berbigier, P., Bernhofer, C., Buchmann, N., Gilmanov, T., and Granier, A.: On the separation of net ecosystem exchange into assimilation and ecosystem respiration: review and improved algorithm, Glob. Change Biol., 11, 1424-1439, 2005.

Rodeghiero, M. and Cescatti, A.: Indirect partitioning of soil respiration in a series of evergreen forest ecosystems, Plant Soil, 284, 7-22, 2006.

Rodríguez-Calcerrada, J., Jaeger, C., Limousin, J. M., Ourcival, J. M., Joffre, R., and Rambal, S.: Leaf $\mathrm{CO}_{2}$ efflux is attenuated by acclimation of respiration to heat and drought in a Mediterranean tree, Functional Ecology, 25, 983-995, 2011.

Rodriguez-Calcerrada, J., Martin-StPaul, N. K., Lempereur, M., Ourcival, J.-M., Rey, M.-d.-C., Joffre, R., and Rambal, S.: Stem $\mathrm{CO}_{2}$ efflux and its contribution to ecosystem $\mathrm{CO}_{2}$ efflux decrease with drought in a Mediterranean forest stand, Agric. For. Meteorol., 195/196, 61-72, 2014.

Ryan, M. G.: Tree responses to drought, Tree Physiol., 31, 237-239, 2011.

Sala, A., Piper, F., and Hoch, G.: Physiological mechanisms of drought-induced tree mortality are far from being resolved, New Phytol., 186, 274-281, 2010.

Salomón, R., Valbuena-Carabaña, M., Gil, L., and GonzálezDoncel, I.: Clonal structure influences stem growth in Quercus pyrenaica Willd. coppices: Bigger is less vigorous, Forest Ecology and Management, 296, 108-118, 2013.

Schulze, E. D., Hall, A. E., Lange, O. L., Evenari, M., Kappen, L., and Buschbom, U.: Long-term effects of drought on wild and cultivated plants in the Negev desert. I Maximal rates of net photosynthesis, Oecologia, 45, 11-18, 1980a.

Schulze, E. D., Lange, O. L., Evenari, M., Kappen, L., and Buschbom, U.: Long-term effects of drought on wild and cultivated plants in the Negev deser. II Diurnal patterns of net photosynthesis and daily carbon gain, Oecologia, 45, 19-25, $1980 \mathrm{~b}$.

Shinozaki, K., Yoda, K., Hozumi, K., and Kira, T.: A quantitative analysis of plant form;the pipe model theory,1, Japan. J. Ecol., 14, 97-105, 1964.

Stauch, V. J., Jarvis, A. J., and Schulz, K.: Estimation of net carbon exchange using eddy covariance $\mathrm{CO} 2$ flux observations and a stochastic model, J. Geophys. Res. Atmos., 113, D03101, 10.1029/2007JD008603, 2008.

Staudt, M., Rambal, S., Joffre, R., and Kesselmeier, J.: Impact of drought on seasonal monoterpene emissions from Quercus ilex in southern France, Journal of Geophysical Research: Atmospheres (1984-2012), 107, ACH 15-11-ACH 15-19, 2002.

Thornley, J.: Respiration, growth and maintenance in plants, 1970.

Valentine, H. T.: Tree-growth models: derivations employing the pipe-model theory, Journal of theoretical biology, 117, 579-585, 1985.

Vesk, P. A. and Westoby, M.: Sprouting ability across diverse disturbances and vegetation types worldwide, J. Ecol., 92, 310-320, 2004.

Vilagrosa, A., Hernández, E. I., Luis, V. C., Cochard, H., and Pausas, J. G.: Physiological differences explain the co-existence of different regeneration strategies in Mediterranean ecosystems, New Phytol., 201, 1277-1288, 2014.

Waring, R. H., Landsberg, J. J., and Williams, M.: Net primary production of forests: a constant fraction of gross primary production?, Tree Physiol., 18, 129-134, 1998.

Wei, W., Weile, C., and Shaopeng, W.: Forest soil respiration and its heterotrophic and autotrophic components: Global patterns and responses to temperature and precipitation, Soil Biol. Biochem., 42, 1236-1244, 2010.

Wieder, W. R., Bonan, G. B., and Allison, S. D.: Global soil carbon projections are improved by modelling microbial processes, Nature Climate Change, 3, 909-912, 2013.

Wiley, E. and Helliker, B.: A re-evaluation of carbon storage in trees lends greater support for carbon limitation to growth, New Phytol., 195, 285-289, 2012.

Wullschleger, S. D. and Hanson, P. J.: Sensitivity of canopy transpiration to altered precipitation in an upland oak forest: evidence from a long-term field manipulation study, Glob. Change Biol., 12, 97-109, 2006. 
Wythers, K. R., Reich, P. B., and Bradford, J. B.: Incorporating temperature-sensitive Q10 and foliar respiration acclimation algorithms modifies modeled ecosystem responses to global change, J. Geophys. Res. Biogeosci., 118, 77-90, 2013.
Zavala, M.: A model of stand dynamics for holm oak-aleppo pine forests, in: Ecology of Mediterranean Evergreen Oak Forests, edited by: Rodà, F., Retana, J., Gracia, C., and Bellot, J., Ecological Studies, Springer Berlin Heidelberg, 105-117, 1999. 